\title{
Fore limb bones of late Pleistocene dwarf hippopotamuses (Mammalia, Cetartiodactyla) from Madagascar previously determined as belonging to the crocodylid Voay Brochu, 2007
}

\author{
Oliver Hampe*, ${ }^{*}$, Daniela Schwarz-Wings ${ }^{1}$, Constanze Bickelmann ${ }^{1}$ and Nicole Klein ${ }^{2}$ \\ ${ }^{1}$ Museum für Naturkunde Berlin, Invalidenstraße 43, 10115 Berlin, Germany. \\ E-mail: oliver.hampe@mfn-berlin.de; d.schwarz-wings@mfn-berlin.de; constanze.bickelmann@mfn-berlin.de \\ ${ }^{2}$ Steinmann-Institut für Geologie, Paläontologie und Mineralogie der Rheinischen Friedrich-Wilhelms-Universität Bonn, Nußallee 8, \\ 53115 Bonn, Germany. E-mail: nklein@uni-bonn.de
}

\begin{abstract}
Received 17 September 2009

Accepted 4 December 2009

Published 3 August 2010

\section{Key Words}

Hippopotamidae

Quaternary

corrigenda

extinction

A humerus and two radii of juvenile dwarf hippopotamuses are redescribed. The subfossil bones from the collection of the Museum für Naturkunde Berlin were erroneously assigned to the horned crocodile Voay robustus (Grandidier \& Vaillant, 1872) by Bickelmann \& Klein (2009). All three limb bones presented here belong to immature animals. The epiphyses are not fused, except the proximal extremity of the right radius; and the radius and ulna are also unfused. The two radii are from individuals of different size, whereas the left radius and the humerus are from animals of similar size. Morphologically, the limb bones cannot be identified to species level. A tentative assignment to Hippopotamus madagascariensis is discussed based on the knowledge of the geographic origin on the island.
\end{abstract}

\section{Introduction}

In 1898, subfossil material of a crocodylian from the late Pleistocene Madagascan locality of Sirabé, North Betsileo (today Antsirabé; Fig. 1) was purchased for the Museum für Naturkunde in Berlin. The material comprises cranial and lots of postcranial material of at least three individuals, and had been labelled as "Crocodylus robustus" Grandidier \& Vaillant, 1872. The taxon "Crocodylus robustus" was revised by Brochu (2007) as having a closer phylogenetic relationship to the genus Osteolaemus (the extant African dwarf crocodile) than to extant Crocodylus. Consequently, the taxon was renamed as Voay robustus (Grandidier \& Vaillant, 1872) (Brochu 2007). Presumably because of the absence of a published record about the material in the Museum für Naturkunde and the absence of a catalogue entry for this specimen, Brochu was not aware of the existence of this material in Berlin and did not include it into his revision. In 2009, Bickelmann \& Klein finally described the material and could convincingly demonstrate that it belonged to the

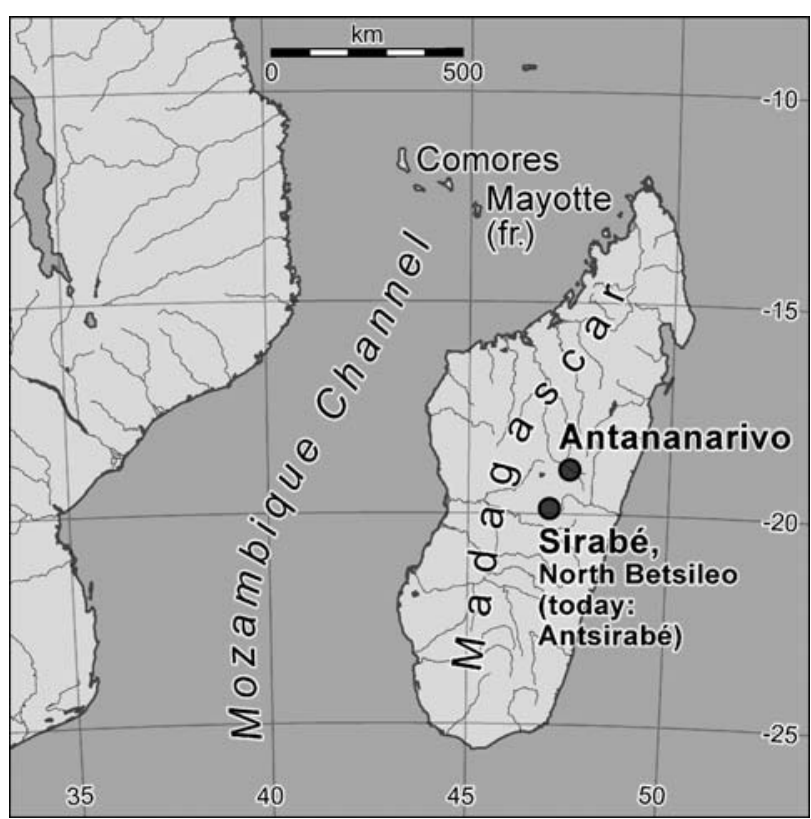

Figure 1. Map of Madagascar showing the locality Sirabé where the hippopotamus limb bones were discovered.

\footnotetext{
* Corresponding author
} 
horned crocodile Voay robustus. After an inventory of the crocodylomorph material in the vertebrate collection it turned out that three of the figured bones by Bickelmann \& Klein (2009, figs $6 \mathrm{G}-\mathrm{H}, \mathrm{J}$ ) cannot be assigned to crocodylians, but belong to dwarf hippopotamuses instead. Thus the specimens have been given new collection numbers with the acronym MB.Ma. (Museum Berlin, collection of fossil mammals) instead of MB.R. (Museum Berlin, collection of fossil reptiles) and will also be kept in a different part of the collection. In that the three specimens have been published and figured already, it is helpful to redescribe them and state their new collection status to avoid confusion.

\section{Systematic Palaeontology}

Class Mammalia Linné, 1758

Superorder Cetartiodactyla Montgelard et al., 1997

Order Artiodactyla Owen, 1848

Superfamily Anthracotheroidea Leidy, 1869

Family Hippopotamidae Gray, 1821

Genus Hippopotamus Linné, 1758

\section{Hippopotamus sp.}

Material. Right humerus (MB.Ma. 51338) and radius (MB.Ma. 51336), left radius (MB.Ma. 51337; old collection number = MB.R.4110).

Age and locality. Late Pleistocene, Sirabé, North Betsileo, today Antsirabé, Central Plateau, Madagascar

\section{Description}

Right humerus MB.Ma. 51338. This element was originally described as an unnumbered crocodylian metacarpal by Bickelmann \& Klein (2009, p. 19). The absence of proximal and distal epiphyses on this bone demonstrates that it does not belong to a crocodylian, but to a mammal. The bone differs also from a crocodylian metacarpal in bearing a distinct proximal crest (deltoid crest, see below), which generally does not occur in crocodylian metacarpals. The distal part of the diaphysis of this bone has a complex morphology with a semicircular prominent posterior depression (olecranon depression, see below), whereas the distal dia- and epiphysis of the metacarpals in crocodylians is spoolshaped with a distinct circular impression on each lateral side.

Instead, the morphology of the bone allows its determination as a right humerus of Hippopotamus. The humeral head and the distal epiphysis (trochlea) are not attached, which indicates that the bone belongs to a very young animal. The shaft of the humerus is slightly twisted, as usual for hippopotamuses (e.g., Kahlke 1997). A prominent deltoid crest is developed on the upper half of the anterolateral face of the shaft (Figs 2A, B). The proximal surface shows a roof-like shape. A deep olecranon depression is developed on the posterior side of the distal end. At the anterior side of the humerus, a larger coronoid depression (medially) and smaller radial depression (laterally), both oviform in outline with a rough surface, can be distinguished. The distal end of the shaft has a slightly triangular outline. The measurements are as follows: length $109.5 \mathrm{~mm}$; proximal width $42.4 \mathrm{~mm}$; distal width $43.8 \mathrm{~mm}$.

Right radius MB.Ma. 51336. This element was described as a second unnumbered crocodylian metacarpal by Bickelmann \& Klein (2009, p. 19). Like the right humerus described above, the absence of a distal epiphysis on this bone is evidence that it does not belong to a crocodylian. The proximal epiphysis is fused to the shaft and possesses two distinct facets, which differ remarkably from the simple, subrounded proximal articular surface of a crocodylian metacarpal. The distal part of the diaphysis again shows no similarities with the spool-shaped distal part (diaphysis plus fused epiphysis) of the metacarpals of crocodylians.

This element is identified as a right radius of a Hippopotamus. The radius is a straight bone with a narrow shaft and expanded proximal and distal extremities. The proximal epiphysis is fused, whereas the distal epiphysis is not preserved, therefore the bone must belong to a subadult individual. The proximal articular surface laterally has a kidney-shaped trochlear facet and medially a nearly triangular radial facet. Both articular facets are slightly depressed and have a smooth surface.

A prominent and rough bicipital tuberosity with the size of a thumbnail is developed below the trochlear facet at the anterolateral face of the radius shaft.

In posterior view the shaft bears a long and slightly depressed upper and lower ulnar articulation surface, separated from each other by a short interosseous border. The outline of the preserved distal end of the diaphysis is somewhat oviform ending in a medially upward bending process for the articulation with the ulna. The measurements are as follows: length $127.7 \mathrm{~mm}$; proximal width $51.0 \mathrm{~mm}$; distal width $51.1 \mathrm{~mm}$.

Left radius MB.Ma. 51337. Bickelmann \& Klein (2009, p. 19) described this bone as a crocodylian phalanx. Crocodylian phalanges have, like the metacarpals, a bilaterally symmetric, spool-shaped distal extremity with typical circular lateral depressions. In contrast, this radius has a highly unsymmetric distal extremity with an upward bending process but without lateral depressions. Furthermore, the proximal articular surface of a crocodylian phalanx is subcircular with a median impression in the pes and sub-oval and slightly convex in the manus. None of these morphologies are present in the proximal extremity of the preserved bone. Both proximal and distal epiphyses are absent on this radius. The fact that epiphyses could be developed exclude this element from the Crocodylia.

Instead, this bone represents a left radius of a Hippopotamus. The absence of epiphyses indicates that the radius belongs to a juvenile specimen. The distal and proximal ulnar articulation facets on the posterior 


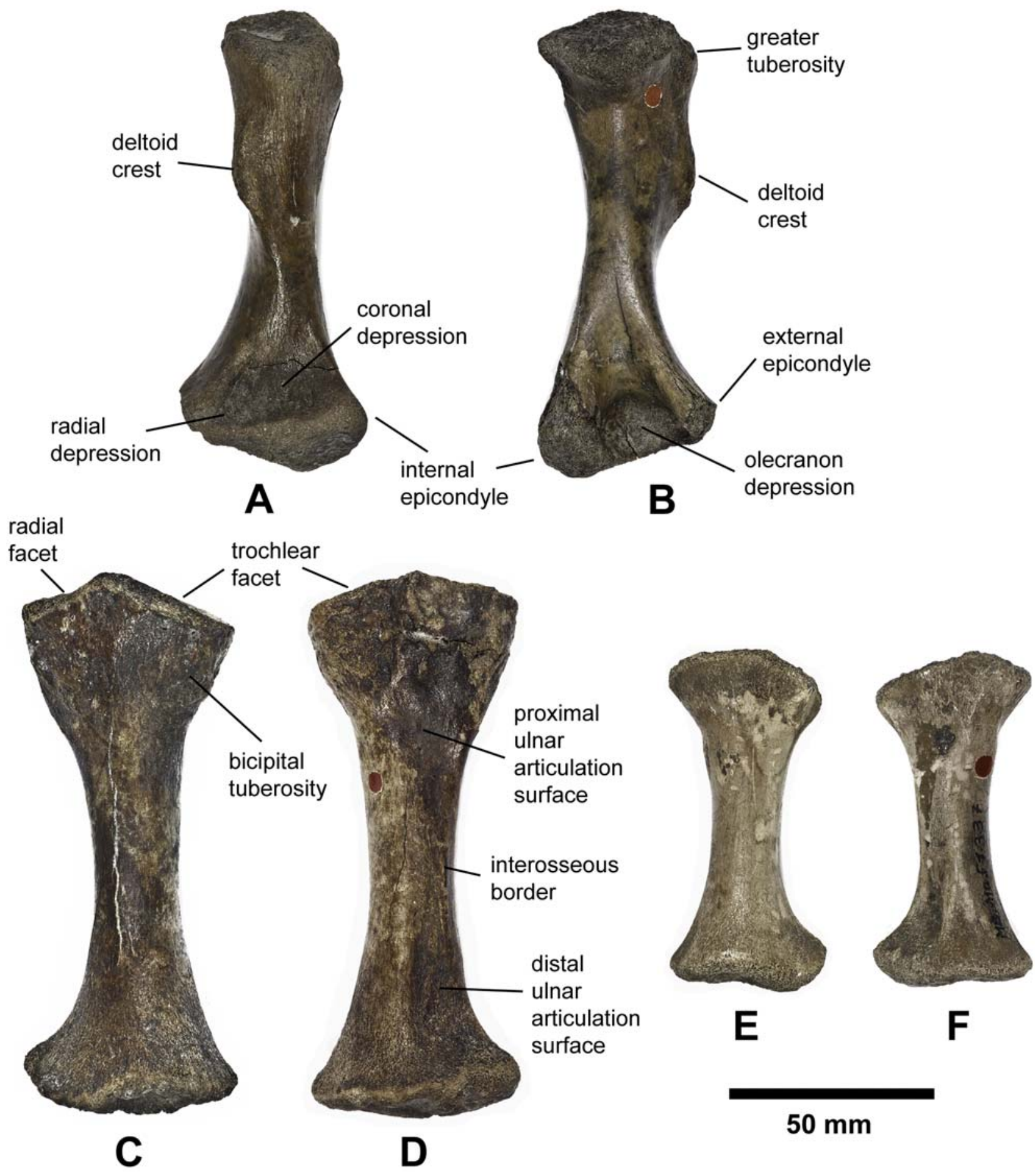

Figure 2. Hippopotamus sp. from the late Pleistocene of Sirabé, North Betsileo (today: Antsirabé). A-B. Right humerus, MB.Ma. 51338 in anterior view (A) and in posterior view (B). C-D. Right radius, MB.Ma. 51336, in anterior view (C) and in posterior view (D). E-F. Left radius, MB.Ma. 51337, in anterior view (E) and in posterior view (F).

side are clearly visible. The interosseous border is a sharp margin situated in front of the ulnar facets and extending over the entire shaft length. The bicipital tuberosity is less prominent than in the above described radius. Compared to the proportions of the humerus, this radius may belong to an individual of nearly the same growth stage. The measurements are as follows: length $77.8 \mathrm{~mm}$; proximal width $37.5 \mathrm{~mm}$; distal width $37.3 \mathrm{~mm}$.

\section{Discussion}

The limb bones redescribed here undoubtedly belong to extinct dwarf hippopotamuses, which are well known from the Quaternary deposits of Madagascar (e.g., Filhol 1895; Forsyth Major 1902a; Joleaud 1923; Stuenes 1989). Two subfossil dwarfed hippopotamuses are known from Madagascar: Hippopotamus lemerlei Grandidier in Milne Edwards, 1868 and Hippopotamus 
madagascariensis Guldberg, 1884. In a substantial contribution, Stuenes (1989) thoroughly described the morphological differences between these species and provided detailed diagnoses. A third extinct Madagascan species, Hippopotamus laloumena Faure \& Guérin, 1990, was proposed by Faure \& Guérin (1990) on limited evidence and a size close to the smallest Hippopotamus amphibius Linné, 1758. Its dissimilarity from Hippopotamus amphibius needs to be clarified.

Morphologically, the preserved bones cannot be determined to species level. Both dwarf hippopotamuses from Madagascar, Hippopotamus madagascariensis and Hippopotamus lemerlei, can only be separated by characters of the skull and the lower jaw (Stuenes 1989).

The bones in question could tentatively be assigned to the species $H$. madagascariensis based on the knowledge of the geographic distribution of the dwarf hippopotamuses on the island Madagascar. Hippopotamus lemerlei is predominantly documented from the southwestern coastal areas, whereas Hippopotamus madagascariensis is known from the central mountain range at heights of about 1,200 $\mathrm{m}$ (Stuenes 1989, fig. 1). This is where the fossilised limb bones from the collection of the Museum für Naturkunde in Berlin came from.

All three limb bones presented here (humerus, radii) unquestionably belong to immature animals. The epiphyses are not fused, except the proximal extremity of the right radius. Furthermore, the radius and ulna become fused during adulthood, which is not the case here. The two radii belong to animals of different size, whereas the left radius and the humerus belong to animals of similar size or even to the same individual.

Pygmy or dwarf hippopotamuses represent common faunistic elements in the limited ecosystems of several islands in the Quaternary, especially in the Mediterranean Sea, like Sardinia (Sondaar et al. 1986), Sicily (Bonfiglio \& Insacco 1992), Malta (Marra 2005), Crete (Kuss 1975), and Cyprus (Forsyth Major 1902b). These dwarf forms are interpreted as having probably derived from African Hippopotamus amphibius-populations (Kahlke 1990; Boisserie 2005). Hippopotamuses from Madagascar became completely extinct about 900 years ago (MacPhee \& Burney 1991).

The extinction of the dwarf island forms was probably caused by late Pleistocene climatic changes and its aftermaths and by human influences in the late Holocene (Dewar 1984; Burney et al. 2004). A cypriote locality discovered in 1980 at the Akrotiri peninsula, for example, revealed over 200,000 accumulated bones and bone fragments of the pygmy hippopotamus Phanourios minutus and the pygmy elephant Elephas cypriotes (Hadjisterkotis \& Reese 2008). They were found accompanied with numerous artefacts - manipulated bones are the evidence for a butchery by humans which populated Cyprus 10,000 years ago. Simmons (1988) and Diamond (1992) considered the colonisation and expansion of humans as the main reason for the decimation and extinction of the dwarf hippopotamuses in general, which would have been a conspicuous prey, easy to locate and to kill. Many islands did not have animals sufficient in size and quantity to offer permanent food for a hunter-gatherer population. The rate of reproduction of the dwarf mammals is low, and after their extinction the hunting population was reduced. An ecological equilibrium could not have been established and continuous human settlement remained (Sondaar et al. 1986).

Similar reasons for extinction have also been considered for the crocodylian Voay robustus by Brochu (2007). In contrast, Bickelmann \& Klein (2009) favour an extinction scenario for Voay by habitat changes and possible modifications in the availability of prey items, and argue against a co-existence of Voay and Crocodylus on Madagascar. However, although there is currently no cranial evidence for such a co-existence within the fossil record, it might well be possible that similar/overlapping morphologies in the postcranium of these taxa hitherto prevented identification of Crocodylus in these deposits. Therefore, until careful comparisons reveal morphological differences in the postcranium of both genera, coeval existence of Crocodylus with Voay cannot be convincingly excluded. A displacement of Voay by the extant Crocodylus niloticus as another reason for the extinction of this taxon can also, therefore, not be excluded.

\section{Acknowledgements}

We are indebted to Detlef Willborn for the access to Recent Hippopotamus bones for comparative purposes in the zoological collection of the Museum für Naturkunde. We would like to thank also Elke Siebert for designing the map and Hwa Ja Götz for photographing the described limb bones. Jason Dunlop kindly checked the English. We also would like to express our thanks to Massimo Delfino, Florence, Ralf-Dietrich Kahlke, Weimar, and Attila Ösi, Budapest, for their constructive and critical reviews.

\section{References}

Bickelmann, C. \& Klein, N. 2009. The late Pleistocene horned crocodile Voay robustus (Grandidier \& Vaillant, 1872) from Madagascar in the Museum für Naturkunde Berlin. - Fossil Record 12 (1): $13-21$.

Boisserie, J.-R. 2005. The phylogeny and taxonomy of Hippopotamidae (Mammalia: Artiodactyla): a review based on morphology and cladistic analysis. - Zoological Journal of the Linnean Society 143 : $1-26$.

Bonfiglio, L. \& Insacco, G. 1992. Palaeoenvironmental, paleontologic and stratigraphic significance of vertebrate remains in Pleistocene limnic and alluvial deposits from southeastern Sicily. - Palaeogeography, Palaeoclimatology, Palaeoecology 95 (3-4): 195-208.

Brochu, C. A. 2007. Morphology, relationships, and biogeographical significance of an extinct horned crocodile (Crocodylia, Crocodylidae) from the Quaternary of Madagascar. - Zoological Journal of the Linnean Society 150: 835-863.

Burney, D. A., Burney, L. P., Godfrey, L. R., Jungers, W. L., Goodman, S. M., Wright, H. T. \& Jull, A. J. T. 2004. A chronology for late prehistoric Madagascar. - Journal of Human Evolution 47: $25-63$. 
Dewar, R. E. 1984. Extinctions in Madagascar. The loss of the subfossil fauna. In Martin, P. S. \& Klein, R. G. (eds). Quaternary extinctions. A prehistoric revolution. University of Arizona Press, Tucson, Arizona: pp. 574-593.

Diamond, J. M. 1992. Twilight of the pygmy hippos. - Nature 359: 15.

Faure, M. \& Guérin, C. 1990. Hippopotamus laloumena nov. sp., la troisième espèce d'hippopotame holocène de Madagascar. Comptes Rendus de l'Academie des Sciences, Serie II 310: 1299-1305.

Filhol, H. 1895. Observations concernant la restauration d'un squelette d'Hippopotamus lemerlei. - Bulletin du Museum d'Histoire Naturelle 1: 88-91.

Forsyth Major, C. I. 1902a. Some account of a nearly complete skeleton of Hippopotamus madagascariensis, Guldb., from Sirabé, Madagascar, obtained in 1895. - Geological Magazine, new series, decade IV 9 (5): 193-199.

Forsyth Major, C. I. 1902b. On the pigmy hippopotamus from the Pleistocene of Cyprus. - Proceedings of the Zoological Society of London 2 (2): 107-112.

Guldberg, G. A. 1884. Undersøgelser over en subfossil flodhest fra Madagaskar. - Forhandlinger i Videnskabs-Selskabet i Christiania 1883 (6): 1-24.

Grandidier, A. \& Vaillant, L. 1872. Sur le crocodile fossile d'Amboulintsatre (Madagascar). - Comptes rendus hebdomadaires des séances de 1'Académie des Sciences 75: 150-151.

Gray, J. E. 1821. On the natural arrangement of vertebrose animals. The London medical repository 15 (1): 296-310.

Hadjisterkotis, E. \& Reese, D. S. 2008. Considerations on the potential use of cliffs and caves by the extinct endemic late Pleistocene hippopotami and elephants of Cyprus. - European Journal of Wildlife Research 54: 122-133.

Joleaud, L. 1923. Sur les hippopotames subfossiles de Madagascar et sur les connexions géographiques recentes de la Grande Île avec le continent Africain. - Comptes rendus hebdomadaires des séances de 1'Académie des Sciences 176: 117-119.

Kahlke, R.-D. 1990. Zum Stand der Erforschung fossiler Hippopotamiden (Mammalia, Artiodactyla). Eine Übersicht. - Quartärpaläontologie 8: 107-118.

Kahlke, R.-D. 1997. Die Hippopotamus-Reste aus dem Unterpleistozän von Untermaßfeld. In Kahlke, R.-D. (ed.). Das Pleistozän von Untermaßfeld bei Meiningen (Thüringen). Teil 1. - Monographien / Römisch-Germanisches Zentralmuseum Mainz 40 (1): 277-374.
Kuss, S. E. 1975. Hippopotamus creutzburgi parvus n. ssp., ein pleistozänes Zwergflusspferd von der Insel Kreta. - Berichte der Naturforschenden Gesellschaft zu Freiburg i. Br. 65: 5-23.

Leidy, J. 1869. The extinct mammalian fauna of Dakota and Nebraska, including an account of some allied forms from other localities, together with a synopsis of the mammalian remains of North America. - Journal of the Academy of Natural Sciences of Philadelphia 7 (2): 1-472.

Linné, C. von. 1758. Systema naturae per Regna tria naturae, secundum Classes, Ordines, Genera, Species, cum Characteribus, Differentiis, Synonymis, Locis. Tomus I. Editio Decima, Reformata. Laurentii Salvii, Stockholm.

MacPhee, R. D. E. \& Burney, D. A. 1991. Dating of modified femora of extinct dwarf Hippopotamus from southern Madagascar: implications for constraining human colonization and vertebrate extinction events. - Journal of Archaeological Science 18: 695-706.

Marra, A. C. 2005. Pleistocene mammals of Mediterranean islands. Quaternary International 129: 5-14.

Milne Edwards, A. 1868. Sur des découvertes zoologiques faîtes récemment à Madagascar par M. Alfred Grandidier. - Comptes rendus hebdomadaires des séances de l'Académie des Sciences 67: 1165-1167.

Montgelard, C., Catzeflis, F. M. \& Douzery, E. 1997. Phylogenetic relationships of artiodactyls and cetaceans as deduced from the comparison of cytochrome $b$ and 12S rRNA mitochondrial sequences. - Molecular Biology and Evolution 14 (5): 550559.

Owen, R. 1848. Description of teeth and portions of jaws of two extinct anthracotherioid quadrupeds (Hyopotamus vectianus and Hyop. bovinus) discovered by the Marchioness of Hastings in the Eocene deposits on the N.W. coast of the Isle of Wight: with an attempt to develop Cuvier's idea of the classification of pachyderms by the number of their toes. - Quarterly Journal of the Geological Society of London 4 (1): 104-141.

Simmons, A. H. 1988. Extinct pygmy hippopotamus and early man in Cyprus. - Nature 333: 554-557.

Sondaar, P. Y., Sanges, M., Kotsakis, T. \& Boer, P. L. de 1986. The Pleistocene deer hunter of Sardinia. - Geobios 19 (1): 19-25.

Stuenes, S. 1989. Taxonomy, habits, and relationships of the subfossil Madagascan hippopotami Hippopotamus lemerlei and H. madagascariensis. - Journal of Vertebrate Paleontology 9 (3): 241268. 